\title{
The Religious Poetry of Michelangelo: The Mystical Sublimation
}

KONRAD EISENBICHLER

Michelangelo was born in 1475 and died in 1564 . His adult life spans one of the most revolutionary periods in the history of the Christian faith. Born, raised and familiar with the pre-Reformation church of Renaissance popes such as Alexander VI Borgia, Julius II Della Rovere, or Leo X de' Medici, Michelangelo was already a grown man of forty-two years of age when, in 1517, Luther posted his 95 theses; he was a still active man of seventy when, in 1545, Paul III convened the Council of Trent; and he was a lucid eighty-nine year-old when, twenty years later, he died just as Pius IV was bringing that historic Council to a close.

A man of profound spirituality and faith, Michelangelo was first influenced by the Neoplatonic philosophers and writers of Laurentian Florence. In the Medicean circles which he entered at the age of fourteen, ${ }^{1}$ Michelangelo came to know the Greek and Roman classics and to partake of the contemporary renewal in Platonic thought through his daily contact and conversation with men such as the philosophers Marsilio Ficino and Pico della Mirandola, or the poets Angelo Poliziano and Lorenzo the Magnificent himself. The most important concept he assimilated from them is, of course, that of the Neoplatonic ascent, through love, to the divinity; a concept which plays an important role in Michelangelo's poetry of the 1530 s and 1540 s (see below, pp.128ff.). Michelangelo never quite shed the Neoplatonism of his youth; even in his old age and when writing poetry inspired by his friendship for the devout noblewoman Vittoria Colonna, Michelangelo was still echoing Neoplatonic concepts. His most famous sonnet, then and now, is "Non ha l'ottimo artista alcun concetto" (G 151: $1538-41 / 44$ ), in which he applies the Neoplatonic concept of the 'idea' to his own art (sculpture) and to his relationship with Vittoria Colonna. ${ }^{2}$ Michelangelo explains that each unworked block of marble contains within it a variety of ideas, or 'concetti,' one of which the sculptor's hand, guided by his 'intelletto,' then chooses to unveil (vv. 1-4). Although in Vittoria Michelangelo can detect both 'morte' and 'pietate,' the only 'concetto' the artist is able to draw out is, much to his dismay, 'morte' (vv. 12-14). 
Earlier lyrics illustrate Michelangelo's awareness and thoughts on other Neoplatonic questions or themes. The sonnet "Quand' il servo il signor d'aspra catena" (G 25; [1524-25?]) considers the question of love in old age and concludes that it is not a sin to love earthly things ('le cose di natura', v. 17) as long as a certain 'peso, termine e misura' is used (v. 18). Besides bringing to mind Baldassare Castiglione's discussion of the question and his similar conclusion in the Libro del Cortegiano (IV, 53-54) - published in Venice in 1528 by Aldus, that is at about the same time as Michelangelo's sonnet was composed - the sonnet's question and conclusion foreshadow and help us to understand Michelangelo's later infatuation with the much younger Tommaso de' Cavalieri.

Highly reminiscent of the theories of the Dolce Stil Nuovo but also very much in line with Castiglione's Neoplatonic definition of love (Cortegiano IV, 51), the fragment "Questa dolcezza al cor per gli occhi porta" (G 38; 1520s) offers Michelangelo's own definition of love:

\section{Amore è un concetto di bellezza immaginata o vista dentro al core, amica di virtute e gentilezza.}

(vv. 9-11)

Thus Michelangelo brings together the Dolce Stil Nuovo link between love and the gentle heart (Guido Guinizelli's canzone "Al cor gentil ripara sempre Amore" comes to mind at this point) and the Neoplatonic concept of beauty as something which is seen or imagined within the lover's soul (and, again, Castiglione's Cortegiano IV, 52 comes to mind).

Alongside this early Neoplatonic influence one must consider the influence of Lorenzo de' Medici's cultural antithesis, fra Girolamo Savonarola, and the turbulent, apocalyptic, religious fervour which engulfed Florence in the last years of the fifteenth century. It seems that Michelangelo heard Savonarola's sermons in the cathedral church of Santa Maria del Fiore in 1493-94. ${ }^{3}$ These sermons dwelt upon the book of Revelations, the first letter of John, the book of Genesis, and the lamentations of Jeremiah. They, and the friar's delivery, touched the sensitive young artist and left a lasting impression on him, an impression that was perhaps made keener by the fact that a few years earlier, in 1491, his elder brother Lionardo had become a Dominican monk and was a follower of Savonarola. ${ }^{4}$ In March 1497, writing under a pseudonym (Piero) from Rome to his brother Lodovico in Florence, Michelangelo reveals his strong sympathy for Savonarola and his own disdain for the decadence and corruption of Rome:

O' auto una lettera tua, della quale ne ho preso grandissimo conforto: massime intendendo de' casi di frate Jeronimo vostro serafico, el quale 
fa dire di lui per tuto Roma, e dicesi ched'è eretico marcio; tanto che bisognia, che venga in ogni modo a profetezare un poco a Roma, e poi sarà canonizato. ${ }^{5}$

The apocalyptic fervour and its accompanying concern with death and the Final Judgement, which gripped Florence in the wake of Savonarola's sermons, can easily be detected in Michelangelo's poetry. The fragment "Chiunche nasce a morte arriva" (G 21; before 1524) reveals Michelangelo's concern with death and the hopeless void associated with it in his early poetry. The poet dwells upon the inevitability of death, the passing of all things, and then imagines a corpse's admonitions to the living. Because the fragment's rhyth mic verse structure is highly reminiscent of Florentine carnival songs ('canti carnascialeschi') and 'frottole,' the poem could be envisioned as a macabre 'Dance of Death' composition. A graphic illustration of this macabre consciousness of the inevitability of death is to be found in the sketch of a skeleton carrying a coffin on his shoulders which, Michelangelo Buonarroti the Younger, reports, adorned the staircase of his uncle's house in Rome; the following epitaph accompanied the sketch:

Io dico a voi c'al mondo avete dato

l'anima e 'l corpo e lo spirto 'nsïeme:

in questa cassa oscura è '1 vostro lato.

(G 110; after 1534-35)

An echo of Savonarola's attacks on the worldliness of the Church is present not only in Michelangelo's above-mentioned letter of 1497, but also, years later, in the "Qua si fa elmi di calici e spade" (G 10;1512) where the poet denounces the militarism and materialism of the people and prelates of Rome. The theme is not new, by any means - Petrarch for one had used it in his Babylonian sonnets to denounce the corruption of the Avignon papacy (sonnets 136, 137, 138). Michelangelo, however, takes it up with renewed fervour and lashes out at the corruption with bitter and sarcastic verses more reminiscent of the fury of the Ferrarese monk than the elegant verses of Laura's lover.

Such attacks on the Church on earth, however, are very much the exception. While in Rome, Michelangelo lived and worked at the pleasure of the papal courts themselves, those of Julius II, Leo X, Clement VII, and, later, of the Counter-Reformation popes; by necessity his personal feelings and opinions would have to be tempered by his employer's politics and practices. Furthermore, as Dante had done in the case of popes such as Boniface VIII, Michelangelo was able to distinguish between the person and the office - while he may have been displeased with Julius II for the manner in which the pontiff behaved towards him (G 6; ca. 1511), 
Michelangelo was still a loyal son of Holy Mother Church, and tempered his words accordingly.

Michelangelo remained, throughout his long life, a practicing and devout Christian who never rejected or questioned the ritual practices and teachings of the Roman church. He attended Mass daily, had prayers said for the successful completion of new endeavours, and firmly trusted in the efficacy both of prayer and of the sacraments. ${ }^{6}$ His adherence to traditional Catholic practices infused his concerns for those close to him as well. When his father fell gravely ill, Michelangelo wrote to his brother Buonarroto (Nov. 23, 1516) begging him to make sure that the old man did not lack the comforts of the soul and the sacraments of the Church:

e quando pure avenissi che egli richaschassi - che Diolui e noi ne guardi, fa'che e' non gli manchi niente delle cose dell'anima e de' sacramenti della Chiesia, e facti lasciare da' llui se e'vuole che noi facciàno cosa nessuna per l'anima sua.?

When his brother Giovansimone passed away, Michelangelo wrote to his nephew Lionardo on January 21, 1548 saying:

Arei caro intendere particularmente che morte à facta e se è morto confessato e comunicato con tucte le cose ordinate dalla Chiesa; perché, quando l'abbia avute e che io il sappi, n'arò manco passione. ${ }^{8}$

Hearing that, in fact, Giovansimone had not received the Sacrament but had espressed contrition for sins committed, Michelangelo responded on February 4, 1548 saying:

Della morte, mi scrivi che, se bene non à avuto tucte le cose ordinate dalla Chiesa, che pure à avuto buona contritione: e questa per la salute basta, se così è. 9

This comment is very important for our understanding of Michelangelo's later poetry. Although a practicing Catholic and a believer both in Purgatory and in the communion of saints, it seems that Michelangelo himself did not partake of the sacrament of penance nor that he prayed to the saints to intercede on his behalf. ${ }^{10}$ Instead, he relied on his own prayers addressed directly to Christ as a substitute for the penitential mediation of a priest or for the intercession of the saints. This new poetry, the fruit of intense personal fervour, was intended only for his own eyes and those of Christ. As poetry became his confessional, its tone became deeply intimate and totally personal.

The major influence in this development was Michelangelo's association, later in life, with exponents of progressive Italian religious thought. 
Through the close friendship he struck up with Vittoria Colonna in 1536 Michelangelo gained an entry into the intense spiritual world of Vittoria herself; a world shaped by Vittoria's confessor Bernardino Ochino (who, although Vicar-General of the Capuchins, would soon flee Italy and become a Protestant; 1542), by Ochino's spiritual father the Spanish reformer and mystic Juan de Valdés, and by cardinals Reginald Pole and Gaspare Contarini, who were actively spearheading the self-renewal of the Roman Church. Contact with Vittoria Colonna and her circle of Catholic reformers had a profound impact on Michelangelo's spirituality and on his poetry. The earlier Neoplatonic and Savonarolan ideals became imbued with a strong element of religious mysticism and fervour. After Vittoria Colonna's death (Feb. 1547), Michelangelo's poetry continued further along the mystical-spiritual path, so much so that it entered into a thoroughly personal world comprised of the poet and his God. His verses now became an expression of his own highly personal relationship with Christ.

In the poetry which predates his encounter with Vittoria Colonna, Michelangelo's attention was attracted by the earthly beauty of young men such as Febo del Poggio or Gherardo Perini. Born in Florence in 1480, Gherardo Perini was a near-contemporary of Michelangelo. Their close friendship dates from about 1520 and although Perini is not mentioned by name in any of Michelangelo's lyrics, a short autograph comment on a sketch of a putto urinating into a vase, the tone of the extant correspondence between the two men, and Aretino's letter of 1545 dealing with the nudes of the Final Judgement all suggest that Perini should be counted among Michelangelo's lovers." ${ }^{11}$ Frey suggests that the poem "Oltre qui fu, dove 'l mie amor mi tolse" (G 36; 1524-34) was in fact inspired by Michelangelo's love for Perini. ${ }^{12}$ The poem is built on the Petrarchan motif of the return to a place associated with the beloved. However, the idyllic recollection of past joys, which would give the poem a Petrarchan atmosphere (see Petrarch's canzone 126, "Chiare fresche e dolci acque"), is replaced by Michelangelo with a play of baroque antitheses which suggest that Michelangelo's feelings were the plaything of his beloved, and by an atmosphere of self-pitying which, after references to the poet's tears and the beloved's departure, culminate in the last verse, 'Colui ch'a me mi tolse e non mi volse' (v. 8). The image of the lover, left forlorn on the rock associated with the beloved, suggests that, as in the case of Ariadne left stranded on the shores of Naxos by Theseus, there is no hope for a return and a reunion.

The Febo del Poggio episode is one of the more unfortunate moments in Michelangelo's love life. His infatuation with the unworthy young model brought no credit to the artist, who soon found himself being approached by the youth with constant demands for money, often bordering on veiled 
blackmail. ${ }^{13}$ Although the affair did not last long, it did inspire a few poems. Two in particular can certainly be associated with Febo, for in both of them the poet plays on the beloved's name. They are the sonnet "Ben mi dove' con sì felice sorte" (G 99; 1535?) and the fragment "Ben fu, temprando il ciel tuo vivo raggio" (G 100; 1535?). In the first poem, there are Neoplatonic elements in the lover's flight to the heavens (vv. 3-4), in the concept of the ladder of love (v. 9), and in the equation of love with light (v. $10)$, but the effect is hardly commensurate. As was the case in the poem for Gherardo Perini ( $\mathrm{G} 36$ ), the final effect is quite different from what was expected: the image left in the poet's memory or in the reader's imagination is not that of a Neoplatonic ascent to the divine, but rather the gloomy, melancholic aftertaste of shattered hopes and unfulfilled desires. The second poem (G 100) remains incomplete, perhaps as an indication of Michelangelo's lassitude about the unfortunate turn of events, or perhaps because, as the opening phrase 'Ben fu' suggests, the fleeting joys of this unfortunate liaison were already felt by the poet to be in the remote past tense.

Gherardo Perini and Febo del Poggio represent for Michelangelo the turmoils and delusions of an unfulfilling and failed physical love. Michelangelo was unable, with either man, to take advantage of the relationship in order to rise to a higher level (G 99) or, at the very least, to enjoy a pleasant memory ( $G 36$ ). The necessary support system for either a Neoplatonic ascension or an idyllic Petrarchan recollection had, in fact, been lacking and the experience developed, as it had started, along the death-oriented path of the physical world.

With the meeting in 1532, and his subsequent infatuation with the handsome and cultured young Roman nobleman Tommaso de' Cavalieri, Michelangelo was obliged to search for a new mode of expression. The elegant, heterosexual, twenty-three year-old youth was extremely flattered but not comfortable with the attention showered upon him by the fiftyseven year-old artist. He was also concerned with the gossip such attention fostered among Roman and Italian evil-tongues. As a result Michelangelo sublimated his sexual interests in the young man, first by emphasizing the spiritual nature of his love, and eventually by underlining how this love lead the lover to a fuller appreciation of the divinity.

The sonnet "Tu sa' ch'i' so, signor mie, che tu sai" (G 60; after 1532) finds its inspiration in Michelangelo's desire to put at ease Tommaso's concerns about the nature of the poet's love for him. In order to re-establish the open friendship that previously had existed between the two men, Michelangelo emphasizes the spiritual element of his love for Tommaso; he speaks of his love for Tommaso's soul rather than for his body (vv. 9-11), and then concludes by discounting the gossip of men who cannot understand the spiritual nature of their relationship (vv. 12-14). 
The Neoplatonic ascension to the divinity is described in an early sonnet to Tommaso, "Veggio nel tuo bel viso, signor mio" (G 83; ca. 1534). The actual physical beauty of Tommaso's face becomes the means by which the poet's soul is able to rise, in contemplation, to God (vv. 1-4). Physical beauty is seen as a reflection, and the only example on earth, of the ultimate beauty of God (vv. 9-13). Again, the "vulgo malvagio, isciocco e rio' which does not understand and derides the love Michelangelo feels for Tommaso is discounted (vv. 5-6). As was the case in the Dolce Stil Nuovo, the poet believes that the ennobling effect of love is experienced by a restricted number of initiates who have risen above the ignorance and insensitivity of the masses. Such descriptions of the Neoplatonic ascension continue to appear in following years; in the sonnet "Non è sempre di colpa aspra e mortale" (G 260; [1546?]) Michelangelo actually mentions that love for physical beauty is the first step ('primo grado') through which. the soul rises to its Creator (vv. 7-8).

In Christian thought, Jesus as the Christ is the intermediary between mankind and God the Father (John 15:16, 16:23, passim). Tommaso's role in Michelangelo's ascension towards the divinity, therefore, becomes closely tied with the figure of Christ, so much so that occasionally a fusion of the two figures seems to occur, a fusion which is visually exemplified in the Sistine fresco of the Final Judgement: Tommaso de' Cavalieri becomes the actual model for the Christus Judex. In a line descending directly from Christ's upraised arm and lowered eyes, Michelangelo then portrays himself in the flayed skin being held up (offered to Christ?) by Saint Bartholomew; the lover thus becomes the devotee, the offering, the martyr, the redeemed.

It is worth noting that in the sonnet "D'altrui pietoso e sol di sé spietato" ( $\mathrm{G} 94 ; 1535$ ), also addressed to Tommaso de' Cavalieri, Michelangelo introduces the image of the silk-worm who offers his life so as to provide a fine cloth as a garment for someone else. In the poem Michelangelo expresses the wish to offer his own skin as a garment for the beloved, so as to be with him, or close to him, all day long (Saint Bartholomew's gesture cannot escape this reader's imagination). The theme of self-sacrifice to the point of martyrdom is present in the very first quatrain when the lowly silkworm is described as 'D'altrui pietoso e sol di sé spietato' (v. 1), and the worm's death is seen in the thoroughly Christian terms of a resurrection to a better life, 'e sol per morte si puó dir ben nato' (v. 4). The second quatrain is centered on the image of a snake which, shedding its skin, is reborn anew. In direct parallel with the end of the previous quatrain, Michelangelo wishes to be that snake which, shedding its skin, is renewed to life (vv. 7-8). The Christian overtones of the two quatrains are, like the snake's skin, quickly shed in the tercets, where the poet's less avowedly Christian and more personal, sexual imagery emphasizes his desire to be physically 
in contact with the beloved, either wrapped around him as a gown wraps a beautiful body (vv. 9-12), or underneath him, trodden by him as a pair of shoes which protect and support their bearer (vv. 12-14).

Although it would seem that the spiritualization and subsequent Neoplatonic elevation of Michelangelo's love for Tommaso de' Cavalieri should resolve the internal turmoils the poet had experienced in the past when a beloved was physically distant (or no longer interested), this is again not the case. In spite of all the assurances on the spiritual nature of his love for Tommaso, Michelangelo does in fact express physical desires that seek fulfilment. Just as Petrarch had, in three short verses, revealed his wish to spend the night with Laura 'e mai non fosse l'alba!' (Canzoniere 22, vv. 31-33), so too Michelangelo imagines Tommaso's embrace and exclaims:

Fermisi in un momento il tempo e l'ore,

il giorno e '1 sol nella su' antica traccia; acciò ch 'i’ abbi, e non già per mio merto,

il desïato mie dolce signore

per sempre nell'indegne e pronte braccia.

(G 72, vv. 10-14; 1533)

The awareness of the physical nature, or the origin, of this affection causes some concern for Michelangelo who thus finds himself torn between the pleasant feelings associated with the attraction he feels for Tommaso and the shame and fear of damnation it elicits in him:

E parte pur m'assale, appresso al dolce, un pensier aspro e forte di vergogna e di morte;

(G 131, vv. 7-9; [ca. 1536?])

The internal turmoil caused by the beloved's physical presence or absence continues to rage inside the poet. In the sonnet "I' mi credetti, il primo giorno ch'io" (G 80; ca. 1533) Michelangelo voices his dilemma to Tommaso: 'appresso m'ardi e nel partir m'uccidi' (v. 14). There really is no final intellectual or spiritual elevation, no resolution for the unfulfilled physical urges and pains the poet feels for his beloved. The philosophical frame offered by the Platonic ladder of love is still very much constructed on physical attractions and forces, still resting upon the senses.

Michelangelo's encounter with Vittoria Colonna in 1536 was a turning point in his spiritual and poetical life. First and foremost, Vittoria was a woman and Michelangelo was obliged to re-examine his concepts of beauty and love. In the sonnet "Non è sempre di colpa aspra e mortale" (G 260; [ca. 1546?]), Michelangelo discusses the Platonic concept of the two 


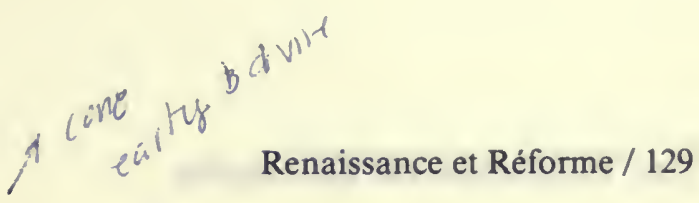

loves, one earthly the other divine, one the physical urge to procreation the other the spiritual aspiration to the 'idea' and, ultimately, to God. While differentiating between the two, Michelangelo says that love for a woman (procreative love) is very different from the love of which he speaks (platonic love for Tommaso), so much so that it is unworthy for a 'cor saggio e verile' to burn for a woman (vv.9-14). Physical love for a woman is then denigrated and discounted. In his affection for Vittoria Colonna, Michelangelo considered her femininity and, ultimately, discounted it; he was not attracted to her for her physical beauty (which even her more generous contemporaries said was not remarkable), ${ }^{14}$ but rather by her spirit and her intellect.

The madrigal "Un uomo in una donna, anzi uno dio" (G 235; 1545?) reflects such a reassessment of reality. Vittoria's speech is at first described as that of 'un uomo' (v. 1 ) - the Renaissance concept of the virago comes immediately to mind - then Michelangelo breaks from the male/female frame of reference and describes her speech as that of a god ('anzi uno dio/ per la sua bocca parla' vv. 1-2). It is worth noting that while Tommaso's divine attribute had always been his physical beauty which, in line with both Dolce Stil Nuovo and Neoplatonic thought reaches the poet through the sense of sight, Vittoria's divine attribute is her intellect which reaches the poet through the sense of speech. Admittedly, her 'bel volto' is mentioned (v. 9), but the poem's impact has already been made by 'la sua bocca' (v. 2) and the poetry has moved to another sphere, that of the word - or the Word, as we can infer from our knowledge of the psycho-religious development Michelangelo was undergoing under her influence.

In the poems addressed to Vittoria, the recurring image is not that of the artist's own ascension through love to the divine, but rather Vittoria's own active involvement with the poet, her moulding of Michelangelo to reshape him into a better, worthier creature. The previous direction of interest has changed; instead of the poet rising to the divine, the divine is bending over to re-form the poet. In one of the earlier compositions addressed to her (G $111 ; 1536$ ?), Vittoria becomes the artist who carves the rock or draws upon the paper which is Michelangelo (vv. 11-13). Later, Michelangelo will ask Vittoria to chisel away at his unnecessary husk to reveal and free his soul (G 152; 1538-41/44). The Neoplatonic theory of the 'concetto' that is revealed by removing the excess covering that envelops it is now turned towards Michelangelo himself. Michelangelo becomes the passive raw material which is ennobled by an active exterior force.

Vittoria's effect on Michelangelo is seen as a heavenly grace which descends upon the unworthy lover; it is a freely-given gift, not a reward for earthly achievements:

E veggio ben com'erra s'alcun crede la grazia, che da voi divina piove, 
pareggi l'opra mia caduca e frale.

L'ingegno, l'arte, la memoria cede: c'un don celeste non con mille pruove pagar del suo può già chi è mortale.

(G 159; undated)

After Vittoria's death (1547), Michelangelo, now in his seventies, seems to leave behind his physical or spiritual infatuations with earthly lovers, male or female, and devotes his energies to a greater, more demanding lover: Christ himself. He develops a direct, private and intense relationship with the Divine Person, a relationship which is the basic element of mysticism. The intimacy of the relationship is seen in terms of a mystical marriage; Christ is the groom, Michelangelo the bride. Michelangelo eagerly submits his own self, adopts the passive role and becomes the obedient partner. Already in his earlier religious poetry Michelangelo had used the imagery of marriage: in the first tercet of "Vorrei voler, Signor, quel ch'io non voglio"' (G-87; ca. 1534) the poet had asked God to ravish him with His grace; in the second tercet the poet had undergone a gender change whereby he became the submissive bride and the beloved became the groom taking possession:

Squarcia '1 vel tu, Signor, rompi quel muro

che con la suo durezza ne ritarda

il sol della tuo luce, al mondo spenta!

Manda 'l predetto lume a noi venturo

alla tua bella sposa, acciò ch'io arda

il cor senz'alcun dubbio, e te sol senta.

(vv. 9-14)

The imagery of the mystical marriage allows Michelangelo to expand his metaphor so as to include the embrace of the groom. Being Christ's, the embrace is immediately translated into the traditional and well-known image of God's re-possession of fallen humanity through the open-armed embrace on the Cross:

Né pinger né scolpir fie più che quieti l'anima, volta a quell'amor divino, ch'aperse, a prender noi, 'n croce le braccia.

(G 285 , vv. 12-14; 1552-54)

For Michelangelo the sacrifice on the Cross becomes the focal point of his relationship with the divinity. Not only is this the elemental sacrifice of love, the breaking of the body and the shedding of the blood which unites the couple, but it is also the ultimate and unique moment of redemption from sin: a concept espoused by liberal Protestants who affirmed the 
uniqueness of the Redemption and rejected confession and good works as steps on the path to salvation. Michelangelo, too, emphasizes the washing away of sin and reconciliation through the shedding of Christ's blood alone: ${ }^{15}$

Tuo sangue sol mie colpe lavi e tocchi

(G 290, v. 12; after 1555)

Signor mie car, tu sol che vesti e spogli, e col tuo sangue l'alme purghi e sani da l'infinite colpe e moti umani

(G 302, vv. 5-7; 1560)

The self-sacrifice of Christ on the Cross invites the self-sacrifice of Michelangelo, who in return offers his own burning self to God (G 92, 170, passim). In the early poems the fire of love had been associated with the fierce fire of a smith's furnace ( $G$ 63; undated), the purifying fire of a goldsmith ( $\mathrm{G} 153 ; 1538-41 / 44)$, or the regenerating fire of the phoenix's funeral pyre (G 61; after 1532). The three images are found together in the sonnet "Sol pur col foco il fabbro il ferro stende" (G 62; after 1532), where their combined effect is still seen within the laws of the physical world; as fire, by its very nature, ascends to the heavens, it will carry with it the poet who is now enflamed by love. Although the classical myth of the phoenix had been appropriated by Christianity as a figure for Christ rising from His own death, in Michelangelo's poetry it does not rise to such Christian overtones. Even in the later poems it remains a mere classical figure to be used in an epithet for Cecchino Bracci (G 217) or to be left implied, as if in a learned nod, in a sonnet on the death of Vittoria Colonna (G 266; undated).

The ultimate refining fire is, of course, the purifying fire of Purgatory, closely akin to the final fire of the Day of Judgement when, in the words of the Dies irae, 'solvet saeclum in favilla.' In the later sonnet "Sì amico al freddo sasso è 'l foco interno" (G 63; Guasti dates it 1542-45) Michelangelo suggests that the fire of love burning fiercely inside him will purify him like the fire of Purgatory and lead him to eternal life.

Michelangelo's attempts to purify himself and rise to God's embrace are thwarted by his constant awareness of the obstacles posed by his own carnality. As was evident in the earlier lyrics, the soul cannot ascend to God because the body, with its passions and demands, keeps it firmly anchored in the material world. When, as an old man, Michelangelo found the embers of earthly, carnal love still smouldering in his heart, his response was an exhausted appeal to Love to be spared for the sake of his advanced age:

I' fu', già son molt'anni, mille volte ferito e morto, non che vinto e stanco 


\section{2 / Renaissance and Reformation}

da te, mie colpa; e or col capo bianco riprendero le tue promesse stolte?

(G 23, vv. 1-4; 1524-25) ${ }^{16}$

The poem suggests that Michelangelo's plea falls on deaf ears and that he remains a prey to his carnality.

In an attempt to overcome such earthly attractions Michelangelo later urges Christ to infuse him with divine love, to let the poet burn with a greater and better fire which, by comparison, will obscure lesser flames: the love for Christ. "Deh, fammiti vedere in ogni loco" (G 274; springsummer 1547) is a powerful example of such a supplication. Through the recurring image of the greater refining fire the poet begs Christ to intercede and renew him inside and out (vv. 7-8). Such imagery recalls the sonnet "La vita del mio amor non è 'l cor mio" (G 34; 1526?), where the last verse described the poet, burning with love, running back into the fire of his beloved's glance. It also recalls the sonnet "D'altrui pietoso e sol di sé spietato" (G 94; 1535), with its image of the snake which sheds its skin and is born anew. In Girardi 274 , however, such a renewal is linked to divine grace rather than to personal merit or will: "ll cangiar sorte è sol poter divino' (v. 14). As had been noticed in the poems directed to Vittoria Colonna, the Neoplatonic ascension is not a factor of the lover's own abilities, but rather a gift given freely by a 'higher' beloved.

The poet examines his own self in preparation for the final union. Inadequacies and faults are brought to mind in an effort to recognize them, confess them and seek absolution, but again the poet's own inability to merit salvation and the importance of God's saving grace, especially through the sacrifice of the Cross, are emphasized (see G 289, 290, 292, 293, passim).

Considering his long life and the number of his sins, Michelangelo despairs of salvation saying that the older one gets the more difficult it is to gain entry into heaven:

Caro m'è sol, perc'anzi morte imparo

Quanto ogni uman diletto ha corta fede;

Tristo m'è c'a trovar grazia e mercede

Negli ultim'anni a molte colpe è raro.

(G 294, vv. 5-8)

As a result of the poet's awareness of his long life of sin, of his perceived inability to merit salvation through his own good works, the poetic relationship between human lover and divine beloved becomes infused with elements present in the earlier love poetry: doubt, self-pity, self-abasement, supplication. Unlike earlier turmoils and doubts, however, the present ones are finally set at rest and resolved; the Christian lover's faith in the 
redeeming power of Christ's sacrifice on the Cross and in His free bestowal of Grace offers a security and a promise which had been lacking in earthly loves. The sonnet "Scarco d'un'importuna e greve salma" (G 290; after 1555) closes with verses which recall the gesture of the Sistine Christus Judex, but which also emphasizes the penitent's prayer for saving Grace freely given:

Non mirin co' iustizia i tuo sant'occhi

il mie passato, e 'l castigato orecchio;

non tenda a quello il tuo braccio severo.

Tuo sangue sol mie colpe lavi e tocchi,

e più abbondi, quant'i' son più vecchio,

di pronta aita e di perdono intero.

(vv. 9-14)

Christ has now supplanted the carnal love for Febo del Poggio or for Gherardo Perini, or the Platonic love for Tommaso de' Cavalieri, or even the spiritual love, built on respect and admiration, for Vittoria Colonna. Christ has become the ultimate beloved. As the poet prepares for His embrace, the conflicts, disappointments and philosophical explanations which had characterized earlier poems recede into the background to be replaced by a constant yet confident prayer for forgiveness and acceptance into the final union. The rapture which Michelangelo could not experience through earthly loves is thus found in the mystical sublimation of earthly passions and the ensuing faith in the saving embrace of the Beloved.

\section{University of Toronto}

Notes

1 Michelangelo lived in the Medici household from 1489 to Lorenzo's death, in 1492.

2 Michelangelo Buonarroti, Rime (Milano: Rizzoli, 1975), p. 212. This edition follows Enzo Noè Girardi's chronology and numbering of the poems. Here and henceforth references to this edition are noted by indicating in parentheses Girardi's numbering of the poem discussed, and, after a semicolon, his suggested date of composition.

3 John Addington Symonds, The Life of Michelangelo Buonarroti (New York: The Modern Library, n.d.) pp. 24-25; Robert J. Clements, The Poetry of Michelangelo (New York: New York University Press, 1965), pp. 104, 129. For a contemporary reference see Ascanio Condivi's Vita di Michelangiolo (Firenze: Rinascimento del libro, 1938), p. 149, where the biographer reports: "Ha similmente con grande studio ed attenzione lette le sacre scritture sì del Testamento Vecchio, come del Nuovo, e chi sopra di ciò s'è affaticato, come gli scritti del Savonarola, al quale egli ha sempre avuta grande affezione, restandogli ancor nella mente la memoria della sua viva voce."

4 Karl Frey, Michelagniolo Buonarroti. Sein Leben und Seine Werke (Berlin: Karl Curtius, 1907), p. 15; see also Robert S. Liebert, Michelangelo. A Psychoanalytic Study of his Life and Images (New Haven and London: Yale University Press, 1983), p. 48.

5 Cited in Aurelio Gotti, Vita di Michelangelo Buonarroti (Firenze: Gazzetta d'Italia, 1876), vol I, p. 22; also in Lettere di Michelangelo Buonarroti, ed. by G. Milanesi (Firenze, 1875), p. 59. The following translation is cited in Robert J. Clements, Michelangelo. A Self-Portrait (New York: 


\section{4 / Renaissance and Reformation}

New York University Press, 1968), p. 66: "I have received one of thy letters, from which I derived the greatest satisfaction, chiefly because of its news of your seraphic Friar Jeronimo, who has set all of Rome to talking. They say here that he is a vile heretic: so much so that somehow he ought to come and prophesy a bit in Rome for these people here; then they would canonise him."

6 Clements, The Poetry of Michelangelo p. 222-23.

7 Michelangelo Buonarroti, Il carteggio di Michelangelo (Firenze: Sansoni, 1965), Vol. I, p. 223. "But if he should happen to have a relapse, which God forfend for him and for us, see that he lacks nothing for the welfare of his soul and that he receives the sacraments of the Church and get him to leave instructions if he wants us to do anything for the salvation of his suul." The Letters of Michelangelo, transl. by E.H. Ramsden (London: Peter Owen, 1963), Vol. 1, pp. 10304.

8 Caneggio IV, p. 289. “I should be glad to hear in detail how he died and whether he died having made confession and having received the Sacrament, together with all those things ordained by the Church; because if he received them and I knew of it, I should be less grieved." Ramsden II, p. 86; Ramsden dates the letter January 16, 1548.

9 Carteggio IV, p. 291. "As to his death, you write me that although he did not receive everything ordained by the Church, he died, nevertheless, in a state of perfect contrition, which, if this is the case, suffices for salvation." Ramsden II, p. 88.

10 Clements, The Poetry of Michelangelo, pp. 222-23.

11 Clements, The Poetry of Michelangelo, pp. 211-12; Liebert considers the same evidence and disagrees with Clements in his Michelangelo, pp. 295-99.

12 Michelangelo Buonarroti, Die Dichtungen des Michelangelo Buonarroti (Berlin: G. Grote'sche, 1897), pp. 320-21.

13 See Giovanni Papini's comments in his Vita di Michelangiolo (Milano: Garzanti, 1952), pp. 334 35; Clements' in his The Poetry of Michelangelo, pp. 134, 213; Liebert, Michelangelo, p. 299.

14 Clements, The Poetry of Michelangelo, p. 196.

15 Such an emphasis on the uniqueness of the Redemption does not necessarily make a Protestant out of Michelangelo; rather, it should be seen within the tradition of mysticism and the central position the Passion occupies in it. Michelangelo's thoughts on the question of 'sola fides' were deeply influenced by Vittoria Colonna's circle of Catholic reformers.

16 Girardi dates the sonnet 1524-25, which would make Michelangelo 50 years old; Frey dates it 1550 , thus making Michelangelo 75 years old. In both cases Michelangelo's age could be considered to be past that of youthful sexual attitudes. 